\title{
Structural, Spectroscopic, and Photochemical
}

\section{Investigation of an Octahedral NO-Releasing $\{\mathrm{RuNO}\}^{7}$}

\section{Species.}

Natalia Levin, ${ }^{\dagger}$ Nicolás Osa Codesido, ${ }^{\dagger}$ Eckhard Bill, ${ }^{*}$ Thomas Weyhermüller, ${ }^{*}$ Ana Paula Segantin Gaspari, ${ }^{\S}$ Roberto Santana da Silva,${ }^{\S}$ José A. Olabe $e^{\dagger}$ and Leonardo D. Slep ${ }^{\dagger, *}$

${ }^{\dagger}$ Universidad de Buenos Aires, Facultad de Ciencias Exactas y Naturales Departamento de Química Inorgánica, Analítica y Química Física, and INQUIMAE, CONICET, Ciudad Universitaria, C1428EHA, Buenos Aires, Argentina.

\$ Max-Planck-Institut für chemische Energiekonversion, Stiftstraße 34-36, D-45470 Mülheim an der Ruhr, Germany.

$\S$ Universidade de São Paulo, Faculdade de Ciências Farmacêuticas de Ribeirão Preto, Departamento de Física e Química, Av. do Café s/n, 14040 - 903 - Ribeirão Preto - SP Brazil 


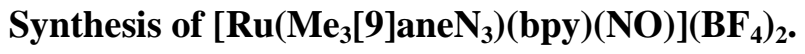

A total of $75 \mathrm{mg}$ of $\left[\mathrm{Ru}\left(\mathrm{Me}_{3}[9] \mathrm{aneN} \mathrm{N}_{3}\right)(\mathrm{bpy})\left(\mathrm{NO}_{2}\right)\right]\left(\mathrm{BF}_{4}\right)(75 \mathrm{mg}, 0.134 \mathrm{mmol})$ was dissolved in $10 \mathrm{~mL}$ of acetone to afford a red solution. Addition of a drop of trifluoromethanesulfonic acid turned the solution into light yellow colored, proper of $\left.\left[\mathrm{Ru}_{\left(\mathrm{Me}_{3}[9] \mathrm{aneN}\right.}\right)(\mathrm{bpy})(\mathrm{NO})\right]^{3+}$. Starting from this point, the reaction mixture was protected from light and thoroughly deaerated with Ar while being stirred. $8 \mathrm{~mL}$ of a deaerated saturated solution of KI in acetone were added dropwise. The solution turned brown and, as the addition continued, a brown-grey precipitate developed. Solid $\left[\mathrm{Ru}\left(\mathrm{Me}_{3}[9] \mathrm{aneN}_{3}\right)(\mathrm{bpy})(\mathrm{NO})\right]_{2}$ was collected by filtration. The IR spectrum of the precipitate showed a band at $1616 \mathrm{~cm}^{-1}$, characteristic of a $\{\mathrm{RuNO}\}^{7}$ compound. The precipitate was dissolved in $10 \mathrm{~mL}$ of deaerated distilled water in contact with a previously $\mathrm{BF}_{4}{ }^{-}$charged, deaerated and dried Dowex 22 anion-exchange resin. The mixture was stirred for 2 hours protected from light, the ion exchange resin was removed by filtration with a Schlenk frit filter and the remaining solution was freeze-dried to afford a brown fluffy precipitate. This precipitate was dissolved in deaerated acetonitrile to afford black crystals suitable for X-

ray analysis after slow diffusion of deaerated diethyl-ether. Anal. Calcd. for $\left[\mathrm{Ru}\left(\mathrm{Me}_{3}[9] \mathrm{aneN}_{3}\right)(\mathrm{bpy})(\mathrm{NO})\right]\left(\mathrm{BF}_{4}\right)_{2}, \mathrm{C}_{19} \mathrm{H}_{29} \mathrm{~N}_{6} \mathrm{OB}_{2} \mathrm{~F}_{8} \mathrm{Ru}\left(\mathrm{MW}: 632.16 \mathrm{~g} \cdot \mathrm{mol}^{-1}\right)$ : C, 36.1; H, 4.6; N, 13.3. Found:

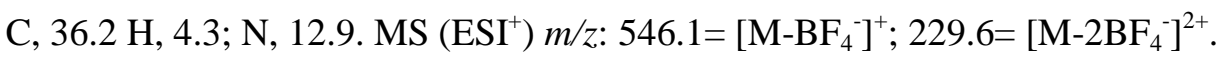

\section{Experimental methods.}

UV-vis spectra were recorded with either an HP8453 or an HP8452A diode array spectrometer. IR spectral measurements were carried out in $\mathrm{KBr}$ pellets, using a Thermo Nicolet AVATAR 320. Microanalytical data for C, H and N were obtained with a Carlo Erba EA 1108 analyzer. ESI spectra were obtained with a standard ESI source and Q Exactive Plus from ThermoFisher Scientific equipment. X-band EPR spectra were recorded at 85K with a Bruker ESP 300 spectrometer equipped with an Oxford ESR 910 liquid-helium cryostat and an Oxford temperature controller. X-band EPR spectra were simulated with EasySpin 5.0.9. ${ }^{1}$ Kinetic studies for the reaction with $\mathrm{O}_{2}$ were performed under pseudo-first order conditions at $\mathrm{I}=1 \mathrm{M}(\mathrm{NaCl})$. A small amount of $\left[\mathrm{Ru}\left(\mathrm{Me}_{3}[9] \mathrm{aneN}_{3}\right)(\mathrm{bpy})(\mathrm{NO})\right]\left(\mathrm{BF}_{4}\right)_{2}$ was dissolved in an argon flushed $\mathrm{CF}_{3} \mathrm{CO}_{2} \mathrm{H}$ buffer solution $(0.1 \mathrm{M})$; which was then treated with variable amounts of an $\mathrm{O}_{2}$ saturated solution. The pseudo-first order kinetic constants $k_{o b s}$ were obtained by multi-wavelength global analysis employing data measured in the UV-Vis-NIR range. Photochemical experiments were performed employing a $365 \mathrm{~nm}$ Light Emitting Diode. The intensity of the 365 
$\mathrm{nm}$ LED $\left(2.44 \times 10^{-6}\right.$ einstein $\left.\mathrm{s}^{-1} \mathrm{dm}^{-3}\right)$ was determined by reference to a $450 \mathrm{~nm}$ LED source employing a FieldMaster-Coherent power meter with a LM-2UV photodiode as light sensor. The $450 \mathrm{~nm}$ LED was calibrated by actinometry employing a standard solution of cis-[Ru(bpy) $\left.{ }_{2}(\mathrm{py})_{2}\right]^{2+}$ (quantum yield of photosubstitution $=0.26),{ }^{2}$ yielding an intensity of $3.61 \times 10^{-6}$ einstein $\mathrm{s}^{-1} \mathrm{~cm}^{-3}$. The quantum yields were determined spectrophotometrically by measuring the spectral changes along the irradiation time under mediumto-high conversion conditions. Factor analysis was employed two confirm the existence of only two colored species, indicating a simple $\mathrm{A} \rightarrow \mathrm{B}$ conversion between the reactant and the product, and was modeled with the following set of equations, where all the symbols have their usual meaning and the factor $f_{\mathrm{A}}$ was introduced to take into account the actual fraction of light absorbed by the reactant

$$
\begin{aligned}
& -\frac{\mathrm{d} c_{A}}{\mathrm{~d} t}=\frac{\mathrm{d} c_{B}}{\mathrm{~d} t}=\mathrm{I}_{\mathrm{A}} \phi_{\mathrm{A}} \\
& \mathrm{I}_{\mathrm{A}}=\mathrm{I}_{0} f_{\mathrm{A}}\left(1-10^{-\sum \varepsilon_{i} b c_{i}}\right) \\
& f_{\mathrm{A}}=\frac{\varepsilon_{A} b c_{A}}{\sum \varepsilon_{i} b c_{i}}
\end{aligned}
$$

\section{X-Ray Crystallographic Data Collection and Refinement of the Structures.}

Crystal structure of compound [1](BF $)_{2}$ was determined with an Oxford Xcalibur, Eos, Gemini CCD areadetector diffractometer using graphite-monochromated Mo-Ka radiation $(\lambda=0.71069 \AA)$ at $170 \mathrm{~K}$. Data was corrected for absorption with CrysAlisPro, Oxford Diffraction Ltd., Version 1.171.33.66, applying an empirical absorption correction using spherical harmonics, implemented in SCALE3 ABSPACK scaling algorithm. ${ }^{3}$ The structure was solved by direct methods with $\mathrm{SIR}^{4} 7^{4}$ and refined by full-matrix least-squares on $\mathrm{F}^{2}$ with SHELXL-2014 ${ }^{5}$ under WinGX platform. ${ }^{6}$ Hydrogen atoms were added geometrically and refined as riding atoms with a uniform value of $U_{\text {iso. }}$. Final crystallographic data and values of $R_{1}$ and $w R$ are listed in Table S1. CCDC 1463223 contains the supplementary crystallographic data for this paper. These data can be obtained free of charge from the Cambridge Crystallographic Data Center via www.ccdc.cam.ac.uk/data_request/cif.

There is only one B-level checkCIF alert (PLAT910_ALERT_3_B Missing \# of FCF Reflection(s) Below Theta(Min) 12 Note). These reflections at low theta angles were fully or in part shaded by the beam stopper. 
$\mathrm{F}(\mathrm{obs})$ values were zero or very small though $\mathrm{F}(\mathrm{calc})$ values were very high. The reflections were therefore removed from the refinement. Though it would have been possible to access these reflections by changing some instrumental setup parameters (the detector could have been placed further from the sample than usual or the default beam-stop mask could have been changed), it is clear from the crystal merit figures that this omission is not important regarding overall crystal refinement quality

\section{Theoretical calculations}

We employed Density Functional Theory (DFT) computations to explore intermediate species involved in the reaction paths described in this report. The calculations were done with Gaussian $03^{7}$ using Becke's three parameter hybrid functional with the correlation functional of Lee, Yang and Parr formalized as the B3LYP

hybrid functional ${ }^{8}$ and the effective core potential basis set LanL2DZ, ${ }^{9}$ which proved to be suitable for geometry predictions in coordination compounds containing metals of the second row of the transition elements in the Periodic Table. We used tight SCF convergence criteria and default setting in the geometry optimizations. The nature of the resulting stationary points was in all cases tested by computing the vibrational spectrum. When needed, solvation effects in aqueous solution were taken into account employing the PCM approximation, as implemented in Gaussian 03. 
Table S1. Crystallographic Data

\begin{tabular}{|c|c|}
\hline & {$\left[\operatorname{Ru}\left(\mathrm{Me}_{3}[9] \operatorname{aneN}_{3}\right)(\mathrm{bpy})(\mathrm{NO})\right]\left(\mathrm{BF}_{4}\right)_{2}$} \\
\hline formula & $\mathrm{C}_{19} \mathrm{H}_{29} \mathrm{~B}_{2} \mathrm{~F}_{8} \mathrm{~N}_{6} \mathrm{ORu}$ \\
\hline $\mathrm{Mr}$ & 632.17 \\
\hline crystal system & monoclinic \\
\hline space group & $\mathrm{P} 2_{1} / \mathrm{n}$, No.14 \\
\hline $\mathrm{a} / \AA$ & $11.0678(4)$ \\
\hline $\mathrm{b} / \AA$ & $10.7139(4)$ \\
\hline $\mathrm{c} / \AA$ & $20.8243(8)$ \\
\hline$V / \AA^{3}$ & $2435.95(16)$ \\
\hline $\mathrm{Z}$ & 4 \\
\hline Dcalc/Mg.m ${ }^{-3}$ & 1.724 \\
\hline $\mathrm{T} / \mathrm{K}$ & $170(2)$ \\
\hline$\mu / \mathrm{mm}-1$ & 0.731 \\
\hline data/parameters & $5294 / 334$ \\
\hline$\theta$ range/deg & $3.73-27.00$ \\
\hline collected/unique refl. & 26788 / 5294 \\
\hline $\mathrm{R} 1, w R 2(\mathrm{I}>2 \sigma(\mathrm{I})) \mathrm{a}$ & $0.0292,0.0636$ \\
\hline R1, wR2 (all data) & $0.0369,0.0678$ \\
\hline GoF (F2) & 1.033 \\
\hline
\end{tabular}


Table S2. Selected bond lengths and angles.

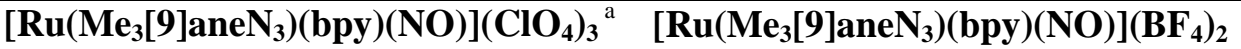

Bondlengths (令)

$\begin{array}{lll}\text { Ru-N1 } & 1.768(4) & 1.852(2) \\ \text { Ru-N2 } & 2.128(4) & 2.169(2) \\ \text { Ru-N3 } & 2.142(3) & 2.151(2) \\ \text { Ru-N4 } & 2.150(3) & 2.145(2) \\ \text { Ru-N5 } & 2.143(3) & 2.113(2) \\ \text { Ru-N6 } & 2.129(3) & 2.109(2) \\ \text { N1-O1 } & 1.135(5) & 1.177(3)\end{array}$

Angles ( ${ }^{\circ}$ )

N1-Ru1-N2

$171.30(15)$

176.11(8)

N1-Ru1-N3

94.3516)

96.32(8)

N1-Ru1-N4

$89.85(15)$

93.37(8)

N1-Ru1-N5

$94.50(14)$

86.98(8)

N1-Ru1-N6

93.84(16)

88.66(8)

N2-Ru1-N3

82.1(13)

81.00(7)

N2-Ru1-N4

82.84(13)

83.49(7)

N2-Ru1-N5

93.88(13)

96.29(7)

N2-Ru1-N6

90.29(13)

94.12(7)

N3-Ru1-N4

81.61(13)

81.85(7)

N3-Ru1-N5

99.61(14)

101.12(7)

N3-Ru1-N6

171.4(13)

174.72(7)

N4-Ru1-N5

176.32(13)

$176.95(7)$

N4-Ru1-N6

101.16(13)

99.68(7)

N5-Ru1-N6

77.13(13)

77.30(7)

Ru1-N1-O1

172.5(4)

141.6(2)

a Reference ${ }^{10}$ 
Table S3. Selected bondlenghts, angles and vibrational frequencies for the known hexacoordinated $\{\mathrm{MNO}\}^{6,7}$ systems.

\begin{tabular}{|c|c|c|c|c|c|c|}
\hline & $\{\mathrm{FeNO}\}^{6 \mathrm{~A}}$ & $\{\mathrm{FeNO}\}^{7 \mathrm{~B}}$ & $\{\mathrm{FeNO}\}^{6 \mathrm{C}}$ & $\{\mathrm{FeNO}\}^{7 \mathrm{D}}$ & $\{\mathrm{FeNO}\}^{6 \mathrm{E}}$ & $\{\text { FeNO }\}^{7 \mathrm{G}, 10}$ \\
\hline N1-O1 / $\AA$ & $1.132(5)$ & $1.166(6)$ & $1.139(3)$ & $1.190(2)$ & $1.141(3)$ & $1.158(6)$ \\
\hline M-N1 / Å & $1.663(4)$ & $1.722(4)$ & $1.677(2)$ & $1.7515(16)$ & $1.634(3)$ & $1.712(3)$ \\
\hline M-Xtrans / $\AA^{\text {a }}$ & $1.883(3)$ & $2.012(3)$ & $1.9009(19)$ & $1.9577(15)$ & $2.005(3)$ & $2.167(2)$ \\
\hline M-N1-O1 / deg & $175.5(3)$ & $148.7(4)$ & $173.1(2)$ & $141.29(15)$ & $179.5(3)$ & $150.4(5)$ \\
\hline $\mathrm{v}(\mathrm{NO})(\mathrm{KBr}) / \mathrm{cm}^{-1}$ & 1904 & 1615 & 1919 & 1615 & $1893^{\mathrm{F}}$ & 1648 \\
\hline
\end{tabular}

Complexes: $\mathrm{A}=[\mathrm{Fe}(\mathrm{NO})($ cyclam-ac $)] \mathrm{Cl}\left(\mathrm{ClO}_{4}\right) \cdot \mathrm{H}_{2} \mathrm{O},{ }^{11} \mathrm{~B}=[\mathrm{Fe}(\mathrm{NO})($ cyclam-ac $)]\left(\mathrm{PF}_{6}\right),{ }^{11}$ $\mathrm{C}=\left[\mathrm{Fe}\left(\mathrm{PaPy}_{3}\right)(\mathrm{NO})\right]\left(\mathrm{ClO}_{4}\right){ }_{2},{ }^{12} \mathrm{D}=\left[\mathrm{Fe}\left(\mathrm{PaPy}_{3}\right)(\mathrm{NO})\right]\left(\mathrm{ClO}_{4}\right),{ }^{12} \mathrm{E}=[\mathrm{Fe}(\mathrm{NO})(\mathrm{pyS} 4)] \mathrm{PF}_{6},{ }^{13} \mathrm{~F}=[\mathrm{Fe}(\mathrm{NO})(\mathrm{pyS} 4)] \mathrm{BF}_{4},{ }^{13}$ $\mathrm{G}=\left[\mathrm{Fe}(\mathrm{NO})\left(\mathrm{pyS}_{4}\right)\right] \cdot 2 \mathrm{CH}_{2} \mathrm{Cl}_{2} \cdot{ }^{13}$

Abbreviations: cyclam-ac=1,4,8,11-tetraazacyclotetradecane-1-acetic acid(-); $\mathrm{Papy}_{3} \mathrm{H}=\mathrm{N}, \mathrm{N}$-bis(2pyridylmethyl)-amine- $N$-ethyl-2-pyridine-2-carboxamide; $\mathrm{pyS}_{4}=2,6$-bis(2mercaptophenylthiomethyl)pyridine(2-).

a Xtrans $=\mathrm{O}$ for $\mathrm{A}$ and $\mathrm{B}, \mathrm{N}$ for the rest of the complexes. 
Figure S1: Packing in the crystal of $[1]\left(\mathrm{BF}_{4}\right)_{2}$.

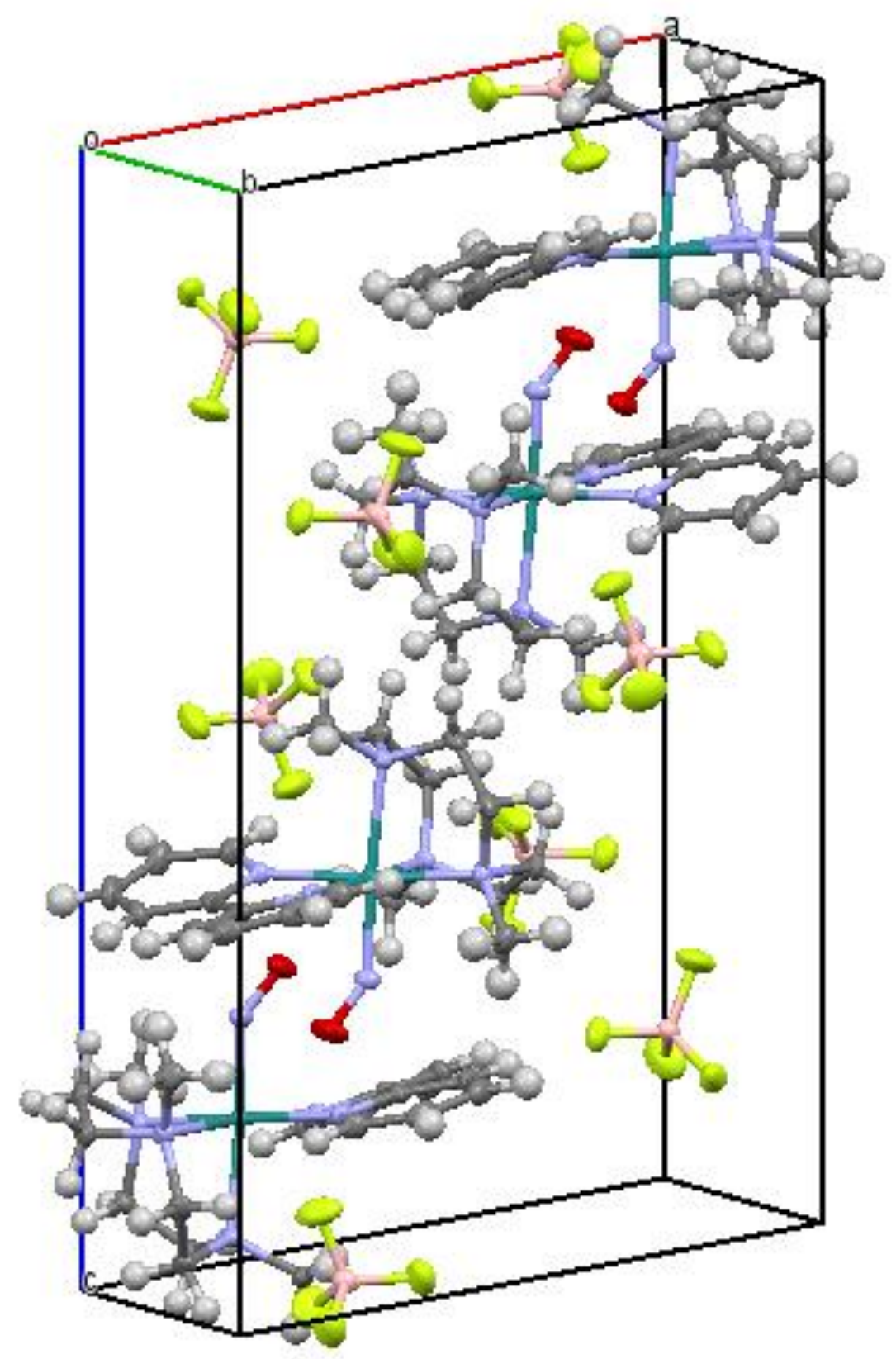


Figure S2: IR spectra $\left(\mathrm{KBr}\right.$ pellet) of $[1]\left(\mathrm{BF}_{4}\right)_{3}$ (top) and $[1]\left(\mathrm{BF}_{4}\right)_{2}$ (bottom).
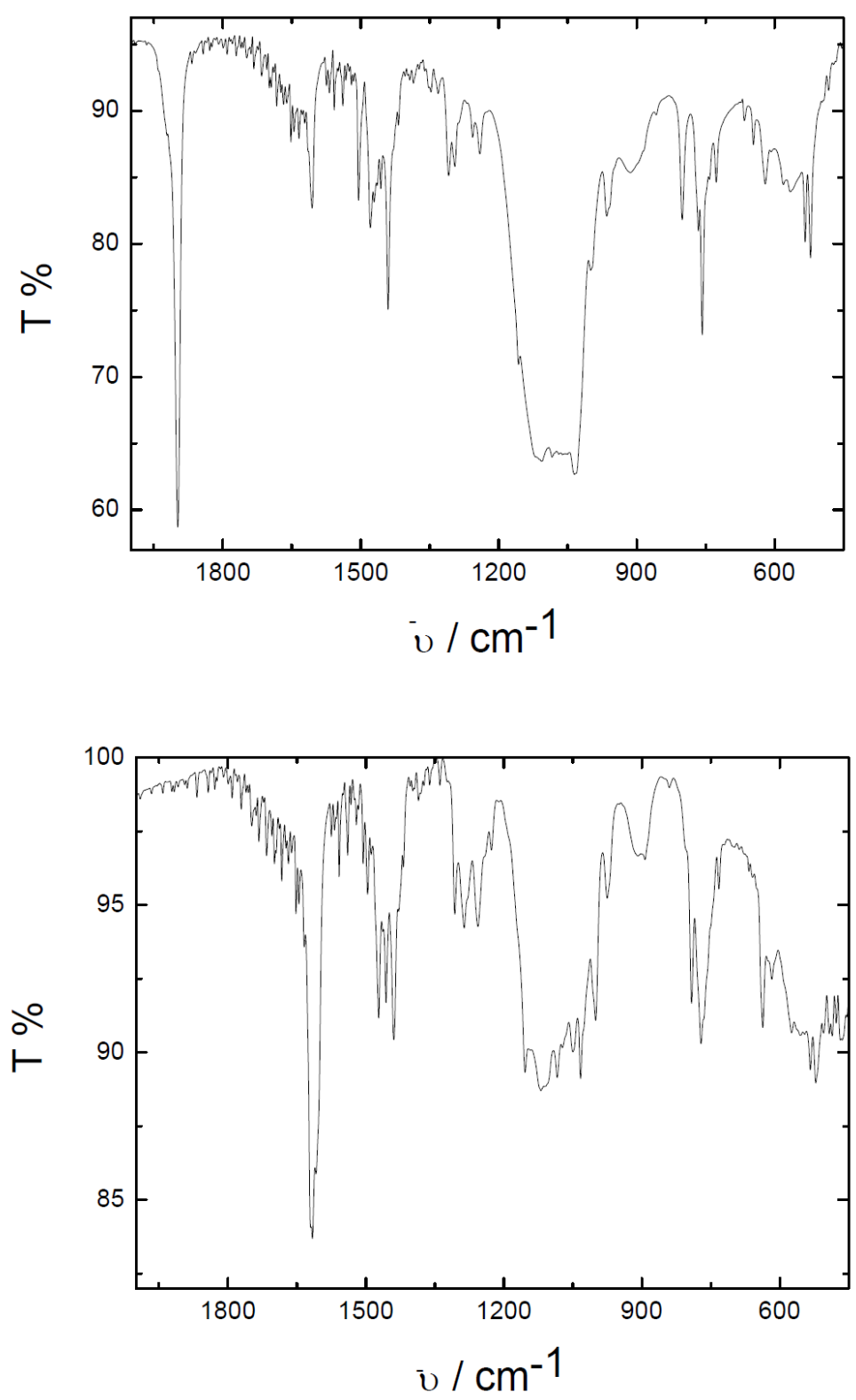
Figure S3. X-band EPR spectrum of the cation $\left[\mathrm{Ru}\left(\mathrm{Me}_{3}[9] \mathrm{aneN}_{3}\right)(\mathrm{bpy})(\mathrm{NO})\right]^{2+}$ in $\mathrm{MeCN} / 0.2 \mathrm{MBu}_{4} \mathrm{NPF}_{6}$ at $85 \mathrm{~K}$. Experimental conditions: microwave frequency, $9.6487 \mathrm{GHz}$; modulation amplitude, 5 G. Bottom: Computersimulated spectrum (see the parameters in the text).

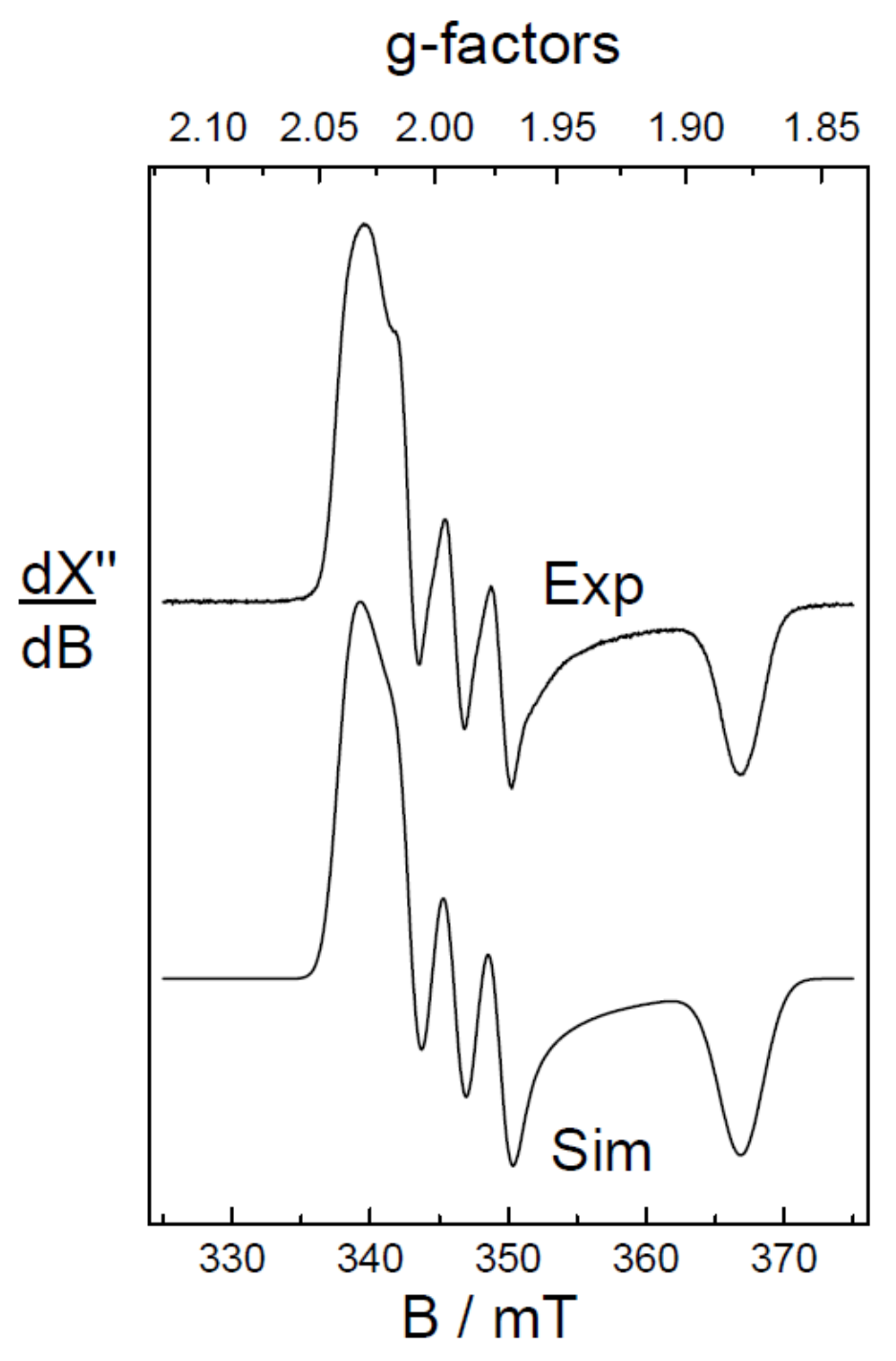


Figure S4. Time trace at $312 \mathrm{~nm}$ of the spectral evolution of $[1]^{2+}$ in aerated solution $\left(0.1 \mathrm{M} \mathrm{CF}_{3} \mathrm{CO}_{2} \mathrm{H}\right.$ buffer, $\left.\mathrm{pH} \approx 2, \mathrm{I}=1 \mathrm{M}(\mathrm{NaCl}), \mathrm{T}=25^{\circ} \mathrm{C}\right)$.

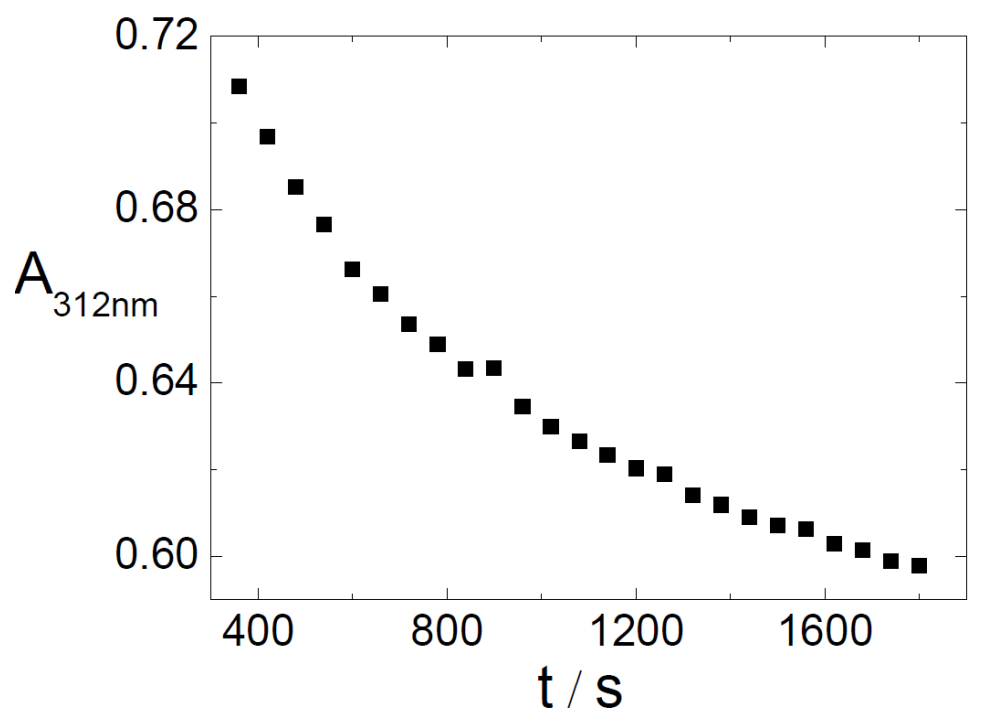


Figure S5. Variation of $k_{o b s}$ with $\left[\mathrm{O}_{2}\right]$. Linear fit: $\mathrm{k}_{\mathrm{obs}}=7.5 \mathrm{~s}^{-1} \mathrm{M}^{-1} \cdot\left[\mathrm{O}_{2}\right]+5 \cdot 9 \cdot 10^{-5} \mathrm{~s}^{-1}$.

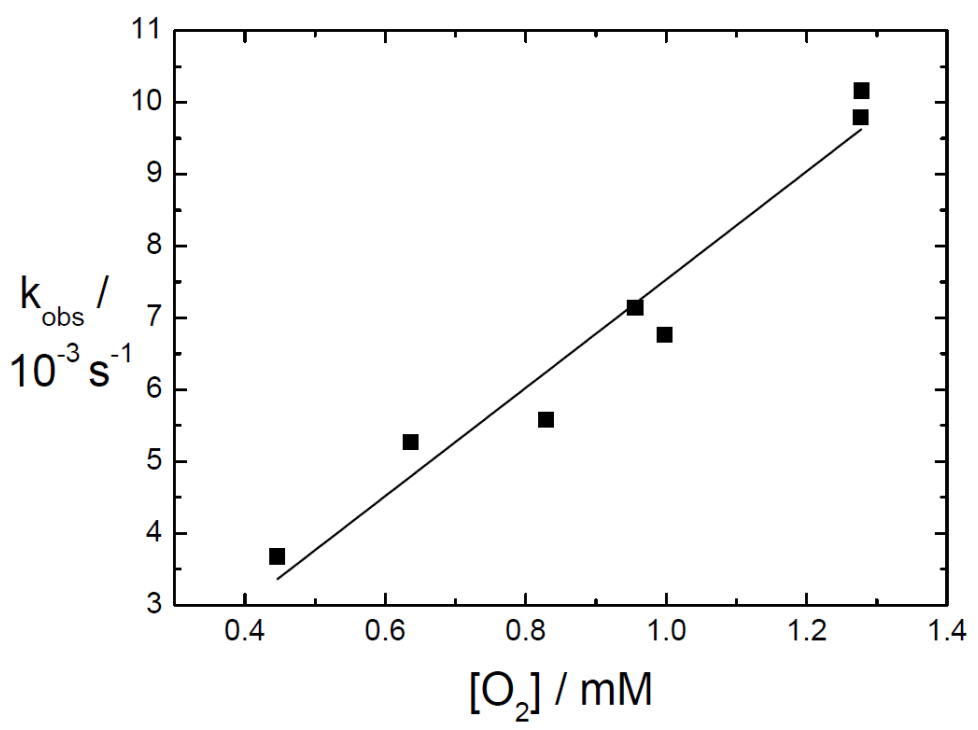


Figure S6. Stoichiometry determination by oxygen titration. Linear fit: $\Delta \mathrm{n}\left(\mathrm{RuNO}^{7}\right)=(3.8 \pm 0.1) \Delta \mathrm{n}\left(\mathrm{O}_{2}\right)$.

The experiments involved dissolution of known quantities of $\left[\mathrm{Ru}\left(\mathrm{Me}_{3}[9] \mathrm{aneN}_{3}\right)(\mathrm{bpy})(\mathrm{NO})\right]\left(\mathrm{BF}_{4}\right)_{2}$ in previously thoroughly deareated with Ar buffer solutions $\left(0.1 \mathrm{M} \mathrm{CF}_{3} \mathrm{CO}_{2} \mathrm{H}\right.$ buffer, $\left.\mathrm{pH} \approx 2, \mathrm{I}=1 \mathrm{M}(\mathrm{NaCl}), \mathrm{T}=25^{\circ} \mathrm{C}\right)$ followed by the addition of a small aliquot of air saturated water solution $\left(\mathrm{O}_{2}\right.$ in defect). The UV-vis spectra of the reaction medium allowed determination of the remaining $\{\mathrm{RuNO}\}^{7}$ concentration upon completion of the reaction (circa $19 \mathrm{hs}$ in the more diluted experiment and 6-8hs in the more concentrated ones). The slope of the plot suggests a 4:1 ratio.

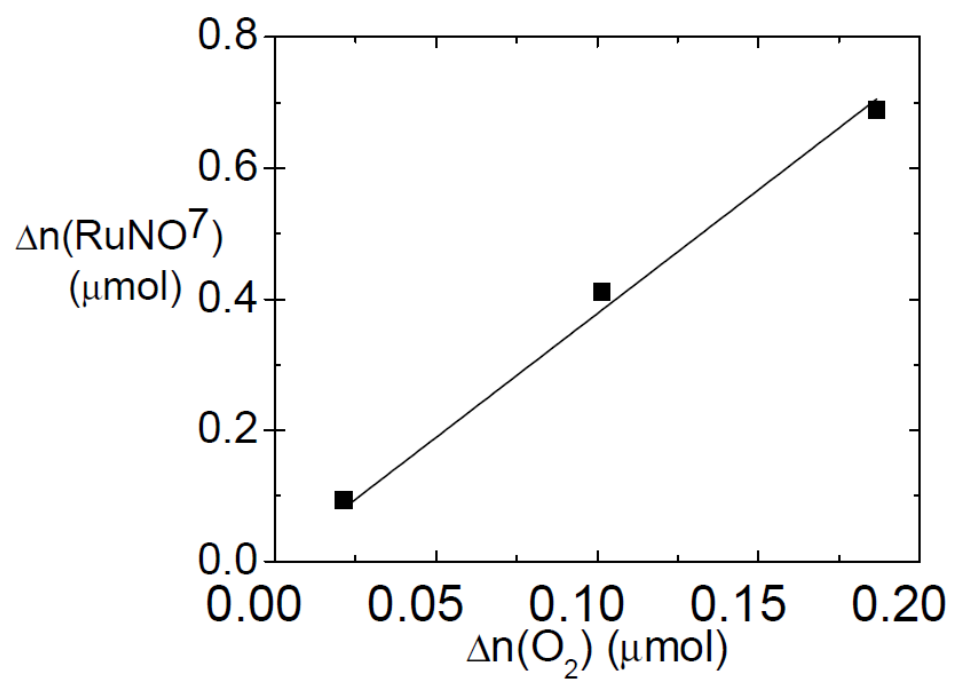


Figure S7. Eyring plot for $[1]^{2+}$ in aqueous solution. Linear fit: $\ln \left(\mathrm{k}_{2} / \mathrm{T}\right)=-1.39 \cdot 10^{4} / \mathrm{T}+1.075$.

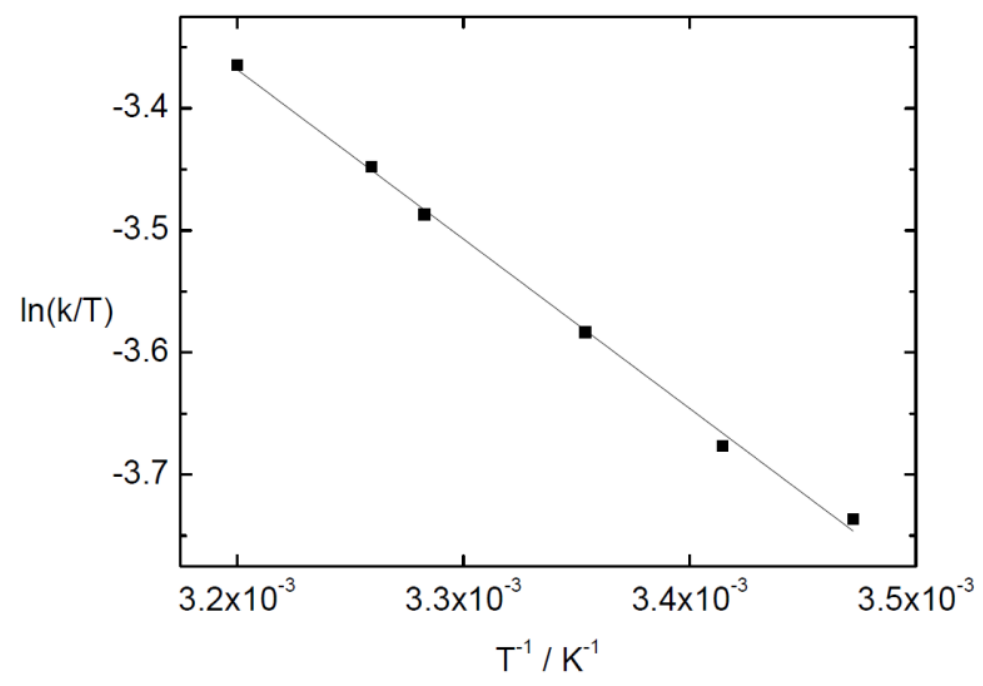


Figure S8. Spectral evolution upon exposure of $[\mathbf{1}]^{2+}$ to $\lambda=365 \mathrm{~nm}$. MeCN. Inset: Conc. profiles calculated for $[\mathbf{1}]^{2+}(\bullet)$ and $[\operatorname{Ru}(\text { solvento })]^{2+}(0)$.

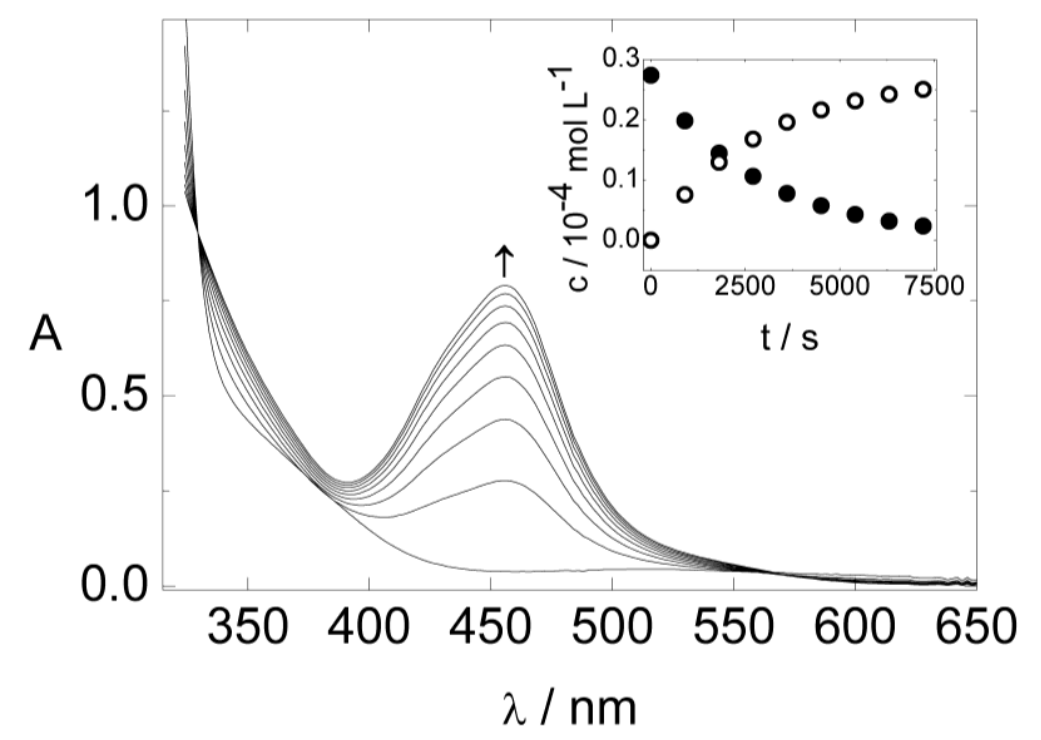


Figure S9. Energetics for the dissociation in the ground and excited states as obtained from DFT in vacuo

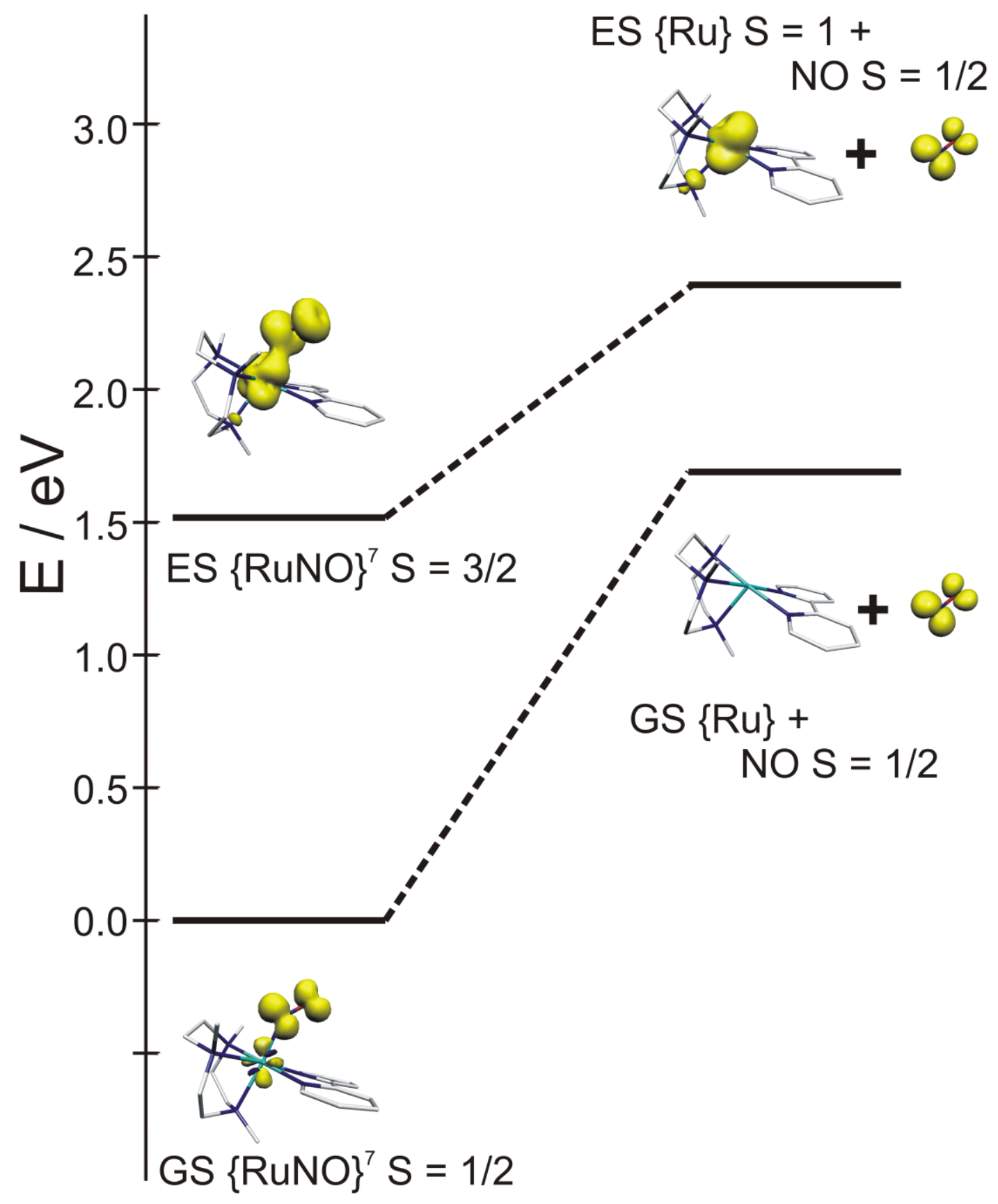


Figure S10. Singly occupied Molecular orbitals for the different species involved in the dissociation processes, as obtained from a Corresponding Orbital Transformation ${ }^{14}$

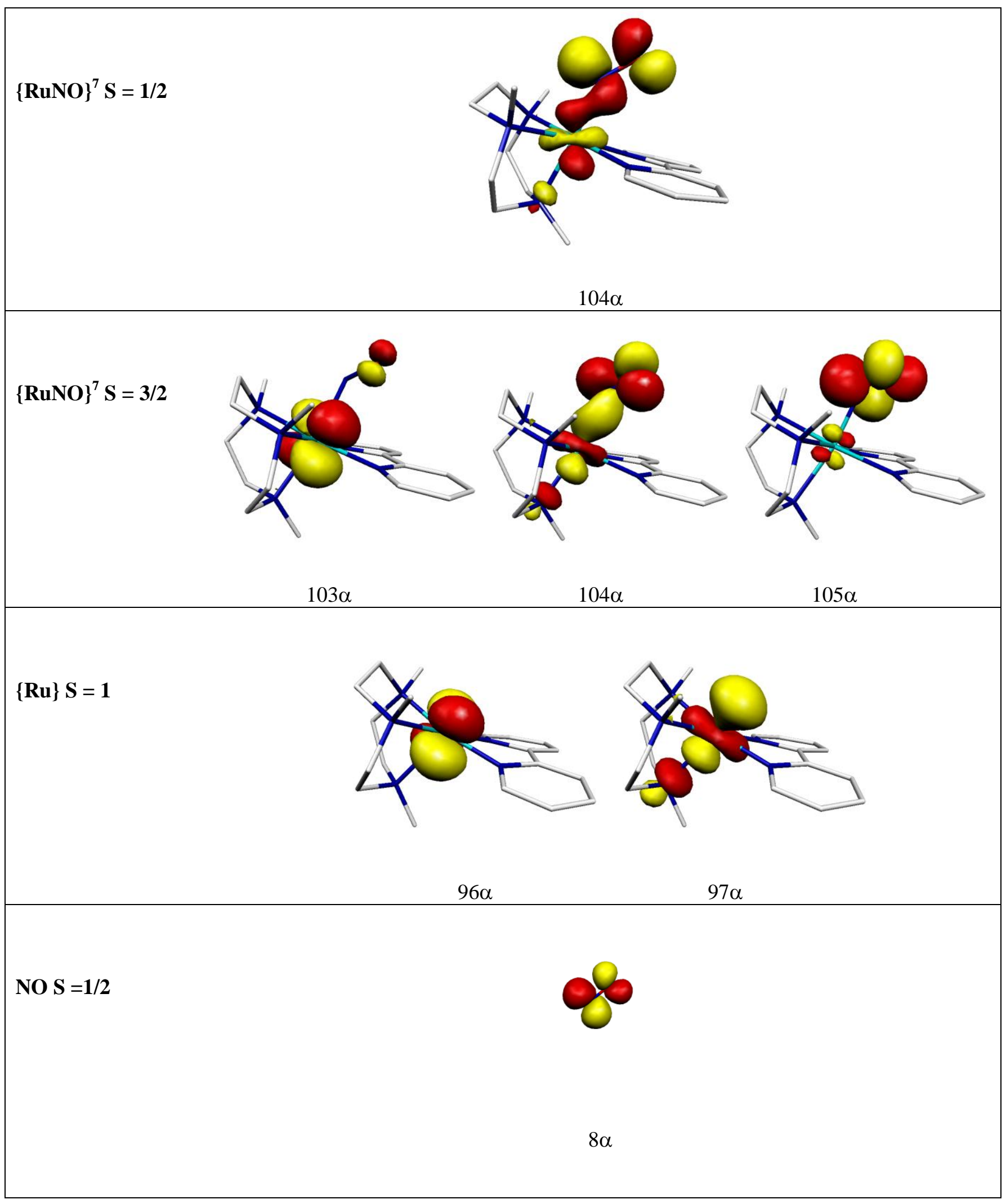




\section{References}

(1) Stoll, S.; Schweiger, A. J. Magn. Reson. 2006, 178, 42-55.

(2) Pinnick, D. V.; Durham, B. Inorg. Chem. 1984, 23, 1440-1445.

(3) SCALE3 ABSPACK Empirical Absorption Correction, CrysAlis, Oxford Diffraction Ltd., 2006

(4) Altamore, A.; Burla, M. C.; Camalli, M.; Cascarano, G. L.; Giacovazzo, C.; Guagliardi, A.; Moliterni, A. G. G.; Polidori, G.; Spagna, R. J. Appl. Cryst. 1999, 12, 115-119.

(5) Sheldrick, G. M. Acta Crystallographica Section A-Faoundations and Advances 2008, A64, 112-122.

(6) Farrugia, L. J. Appl. Cryst. 2012, 45, 849-854.

(7) Frisch, M. J. Gaussian 03, Rev. C.02 and D.01, Gaussian Inc., Wallingford CT, 2004

(8) (a) Becke, A. D. J. Chem. Phys. 1988, 84, 4524-4529; (b) Becke, A. D. J. Chem. Phys. 1993, 98, 5648-5652; (c) Lee, C.; Yang, W.; Parr, R. G. Phys. Rev. B 1988, 37, 785-789; (d) Perdew, J. P. Phys. Rev. B 1986, 33, 8822-8824.

(9) (a) Dunning Jr., T. H.; Hay, P. J. Modern Theoretical Chemistry. In Modern Theoretical Chemistry; Schaefer III, H. F., Ed.; Plenum: New York, NY, 1976; pp 1-28; (b) Hay, P. J.; Wadt, W. R. J. Chem. Phys. 1985, 82, 270-283; (c) Hay, P. J.; Wadt, W. R. J. Chem. Phys. 1985, 82, 299-310; (d) Wadt, W. R.; Hay, P. J. J. Chem. Phys. 1985, 82, 284-298.

(10) Osa Codesido, N.; Weyhermüller, T.; Olabe, J. A.; Slep, L. D. Inorg. Chem. 2014, 53, 981-997.

(11) Serres, R. G.; Grapperhaus, C. A.; Bothe, E.; Bill, E.; Weyhermuller, T.; Neese, F.; Wieghardt, K. J. Am. Chem. Soc. 2004, 126, 5138-5153.

(12) Patra, A. K.; Rowland, J. M.; Marlin, D.; Bill, E.; Olmstead, M. M.; Mascharak, P. K. Inorg. Chem. 2003, 42, 6812.

(13) Sellmann, D.; Blum, N.; Heinemann, F. W.; Hess, B. A. Chem.-Eur. J. 2001, 7, 1874-1880.

(14) King, H. F.; Stanton, R. E.; Kim, H.; Wyatt, R. E.; Parr, R. G. J. Chem. Phys. 1967, 47, 19361941. 